\title{
Preliminary aspects of a qualitative research projection
}

Simona Haidău, University Assistant PhD Student, University Vasile Alecsandri of Bacău

\begin{abstract}
In this paper are presented preliminary aspects on the design of of qualitative research achieved by nongovernmental organizations in the North-East of România. The research aims to identify attitudes, opinions and behaviors to nongovernmental organizations to implement public relations programs and campaigns.
\end{abstract}

\section{Keywords}

private administration, nongovernmental organizations, associations, foundations, public relations, campanign

\section{JEL Codes: L31, M31}

\section{Introduction}

In the current period, when competition is increasingly fiercer, and communication budgets are downward trend, underline the fact that advertising can not be the only answer to the la the increasingly complex marketing problems. Modern marketing increasingly impose combining specific activities of advertising, sales promotion, direct marketing and public relations.

The role and importance of public relations activity increased in importance during the economic and social development, gradually becoming the significant and distinct activity of contemporary society. As a distinct field of economic agents activity, the public relations will be between the most effective tools of communication policy in contemporary society comprising promotional obvious valences.

Public relations applications are found in almost every human activity. Public relations are used in organizations, regardless of where they operate, such as economics, finance, politics, government, education, healthcare, nonprofit organizations, arts, sports, tourism, etc. Diversity range of organizations leads to a understanding and hence the practice field.

The present study is projected to assess the extent to which nongovernmental organizations apply the public relations system in the current socio-economic context and it is based a series of assumptions and hypotheses meant to give more value through the prospect of results and the possibilities for their operationalization.

\section{Marketing qualitative research methodology at nongovernmental organizations from North-East region}

\subsection{Decision problem definition, purpose, hypothesis and research objectives}

Decisional problem that will be the realization of this research is the knowing the extent to which nongovernmental organizations apply public relation system, namely various specific programs and campaigns. 
Purpose of research defined as an extension of decision problem will guide the whole research to identify attitudes, opinions and behavior nongovernmental organizations on the implementation of public relation programs and campaigns.

Key assumptions of qualitative research are:

H1: nongovernmental organizations attaches great importance to the process of communication with target audience;

$\mathrm{H} 2$ : more than half of nongovernmental organizations apply PR system by implementing various programs and campaigns;

H3: over half of the nongovernmental organizations prefer public relations activity to attract funds / volunteers, compared with publicity actions;

$\mathrm{H} 4$ : over half of the nongovernmental organizations prefer public relations activity to making known the services offered;

H5: variables that influence decisions to initiate programs and public relations campaigns by private government organizations studied are mainly discrete variables.

Research objectives that will lead to achieving the proposed goal are:

- knowledge of nongovernmental organizations views on the importance of the communication process with target audience;

- identify the knowledge and opinions nongovernmental organizations towards public relations programs and campaigns;

- knowledge of nongovernmental organizations views on public relations techniques at witch can call;

- knowledge of the decisional variables nongovernmental organizations in selecting programs and public relations campaigns.

\subsection{Choosing data sources and methods of gathering information}

Based on the benchmarks for their achievement will be used primary data sources, namely, information will be provided by persons authorized by the nongovernmental organizations.

Qualitative research method chosen will be interviewed in depth semiconducting.

This type of interview is a variant of in depth interview undirected, since:

- remain valid principles of non-directivity;

- attitude of investigator should be neutral, it must having to respect the same rules as for in-depth interview undirected;

- sample construction is done in the same way;

- interview is recorded on magnetic tape and then will be subject to a content analysis.

Unlike in-depth interview unmanaged, semiconducting interview is performed using an interview guide (also called conversation guide), devised in advance.

The interview guide contains topics that should be addressed during the discussion (about 56 themes set according to the research objectives). The topics will be introduced by the investigator only if the respondent did not addressing the spontaneous. Is not necessary to respect a certain order: will be discussed according to the closeness of in relation to the topics addressed by the interviewee.

A view to developing the interview guide, should be noted that this is not a questionnaire with open questions and fall time between 30 minutes and an hour.

\subsection{Defining community and identifying units under investigation}

In-depth interview sample means addressing subjects in terms of relevance and intrinsic value of information which they hold. It requires a rigorous selection for not being compromised research process is well known that from other research nature of the information obtained has the highest degree of privacy in relation to opinions subjects 
interviewed. Regarding the recruitment to the participants in-depth interview semiconducting will use a filter questionnaire to be disposed unwanted attributes of subjects.

\section{Recruitment questionnaire}

1. Have you participated in in-depth interviews semiconducting similar last 6 months?

- yes $^{1}$

- no

2. Please type nongovernmental organization in which you are:

3. Please indicate the main field of activity of the nongovernmental organization you represent:

- culture, art, sport, recreation

- education, research

- health

- social services

- protection of the environment

- economic and social development

- protection of rights and promote the interests of citizens

- women's rights and gender equality

- philanthropy and volunteering

- international cooperation

- business and professional interests representation

- religion

Considering the purpose and objectives of qualitative research, community from the level to be selected the units subject to interview will be composed of all nongovernmental organizations which they operate in the northeast region.

Units investigated are the nongovernmental organizations which they operate in various fields such as:

- Bethany Association - field: social services;

- Youth Association Onesti - field: culture, art, sport, recreation;

- We love Nature Association - field: environmental protection;

- Agnesiana Association - field: culture, art, sport, recreation;

- Association for Promoting Diversity in Education - field: education and research;

- Community Support Foundation - field: social services;

- Association Oblio - field: culture, art, sport, recreation;

- Caritas Association - field: social services;

- John Bosco Foundation - field: culture, art, sport, recreation.

\subsection{Prepare the material conditions for data collection and developing research tools}

Conducting the interview will involve using as data collection tool - guide the interview or conversation. The objectives set the previously be addressed under the guide in four subjects: Topics included in the conversation guide:

- nongovernmental organizations views about the importance communications process with target audience;

- knowledge and opinions of nongovernmental organizations by public relations programs and campaigns;

- nongovernmental organizations views with regard to public relations techniques available to them;

\footnotetext{
${ }^{1}$ If the answer is affirmative selection process is stopped at the interview organizations
} 
- the decisional variables nongovernmental organizations in selecting programs and public relations campaigns.

For the smooth conduct of interview, by the idea of eliminating weight approach to the topics under discussion (offering insufficient information for purpose of research), will proceed to address issues with a greater degree of detail. Thus, for each theme will determine topics as:

- known vectors of communication; advertising or public relations; differences existing between the two techniques of communication: advertising, public relations; motivation by election advertising as communication techniques; motivating choosing public relations as a means of communication;

- concept of public relations; strengths and weaknesses of public relations activity; frequency of calls to the public relations activity; public relations activity with its own forces or by resorting to specialized people outside the organization; favorable conditions by implementation of the public relations system (to gain confidence; to communicate and transmit messages reliably with regard to activities, initiatives, projects under the participatory citizenship, solidarity and altruistically; to maintain a close relationship with the public to achieve the objectives $==>$ donor-recipient relationship; in order to raise funds and volunteers; for promotion - public opinion aware about the importance of nongovernmental organizations activities; for creating, maintaining and improving the image of nongovernmental organizations); advantages and disadvantages of implementing public relations fields nongovernmental organizations;

- public relations techniques known; views on a variety of public relations techniques available to them; the order preference regarding public relations techniques used; nongovernmental organizations preferences for certain public relations techniques based on goals formulated;

- internal variables: people age from the level of nongovernmental organizations management; efficiency of financial, material and time consumption; possibility of using various media channels; external variables: sociodemographic (age, sex, marital status, occupation, residence, education level, social class and income groups of population, lifestyle) natural; cultural; technology; political and legislative.

For conducting the interview will be using a video camera that allows full recording of the interview, giving a much richer material for analyzed in comparison with data recorded using a tape recorder. Support video recording of the interview was accepted by subjects with conditions guaranteeing their anonymity and destruction of material recorded information held immediately after completion of the analysis. Another tool for collecting the information is card will be used to annotate operator of words or themes that can be deepened further.

\subsection{Collecting information}

Collection of data will be done after conducting in-depth interviews that will be subject nongovernmental organizations from northeast region. The interview will involve open discussion between "researcher" and the subject interviewed.

Shall be observed the principles of non-directivity, such as: avoidance orientation discussion by imposing a certain structure, inducing responses, interpretation, approval or disapproval, making observations or interruptions of the person interviewed.

Also the interviewer will be able to intervene in the discussion following: ease of discourse, to deepen themes approached, listen carefully interviewed subject, indicating that it is understood, as well as an overview of the interviewees with respect logic statements it.

During the interview will address the issues set out in the interview guide, by making a detailed these form a more complex by the interviewees. The themes will not have a preset 
order and operator interview intervention in the discussion will be necessary only in cases of recovery of the discussion.

People from non-governmental organizations which will be qualitative research and were subjected to interview representing people in management organizations or within the public relations department.

\section{Bibliography}

1. Balaure, V. (2002), Marketing Ediţia a II-a revăzută şi adăugită, Ed. Uranus, Bucureşti

2. Cătoiu, I. (coordonator), Bălan, C., Popescu, I.C., Orzan, GH., Vegheş, C., Dănețiu, T., Vrânceanu, D. (2002), Cercetări de marketing, Ed. Uranus, Bucureşti

3. Cătoiu, I. (coordonator) (1999), Metode şi tehnici utilizate în cercetările de marketing. Aplcații. Ed. Uranus, București

4. Florescu (coord.), C., Balaure, V., Boboc, St., Cătoiu, I., Olteanu, V., Pop, N.Al. (1992), Marketing, Ed. Marketer, Bucureşti

5. Kotler, Ph. (2000), Managementul marketingului, ediţia a II-a, Ed. Teora, Bucureşti

6. Kotler, Ph. (2000), Principiile marketingului, ediţia a II-a, Ed. Teora, Bucureşti

7. Lefter, C. (1996), Cercetarea de marketing. Teorie şi practică, Ed. Lux Libris, Braşov

8. Popescu, I. C. (2000), Metode calitative utilizate în cercetările de marketing, Ed. ASE, Bucureşti

9. www.cdep.ro 